\title{
シクロホスファミド調製時におけるシリンジプランジャー污染の検証
}

\author{
前田章光*，高橋新次，栗原幸司，梶田正樹，水谷旭良 \\ 愛知県がんセンター中央病院 薬剤部
}

\section{Investigation of Syringe Plunger Pollution with the Cyclophosphamide Preparation}

\author{
Akimitsu Maeda*, Shinji Takahashi, Koji Kurihara, Masaki Kajita and Akiyoshi Mizutani \\ Departments of Pharmacy, Aichi Cancer Center Hospital \\ $\left[\begin{array}{l}\text { Received April 29, } 2015 \\ \text { Accepted July 21, 2015 }\end{array}\right]$
}

Use of a closed system drug transfer device is effective in decreasing the exposure of medical staff to anti-cancer drugs. However, the exposure of a syringe plunger to anti-cancer drugs during preparation has not been validated. Therefore, we conducted a study to examine the drug pollution of the syringe plunger after cyclophosphamide (CPA) preparation. In the present study, CPA were detected in all syringe plungers that had been used in CPA preparation (median: $2.97 \mathrm{ng}$, range: 0.681-68.2 ng). Therefore, using the same syringe for administering two or more injections could increase the risk of CPA exposure for the medical staff.

Key words — closed system drug transfer device, anti-cancer drug, cyclophosphamide, syringe plunger

\section{緒言}

抗がん剂を取扱う医療従事者は，長期的に抗が ん剂に曝露されることにより，健康被害を生じる 可能性が懸念されている. ${ }^{1}$ 抗がん剂調製時の曝 露を軽減させる方法として閉鎖式薬物混合デバイ ス (closed system drug transfer device: CSTD) の 有用性が知られており，近年，シクロホスファミ ド（cyclophosphamide: CPA）を中心としたアル キル化剂に対して広く使用されている。しかしな がら，CSTDを用いた調製においても医療従事者 に対する抗がん剂曝露は完全に消失したとは言い 難い，特に調製者の手袋に対する抗がん剂の付着 は PhaSeal ${ }^{\circledR}$ や ChemoCLAVE ${ }^{\circledR}$ な゙の CSTDを用い た調製後にも認めている. ${ }^{2}$ 調製者の手袋に付着 した抗がん剂は, 調製者の手指を介して, 輸夜バッ ク等に伝搬され，患者のベッドサイドなど院内全 体に抗がん剂污染が拡散する可能性を有している ことから, 調製者の手袋への抗がん剤の曝露は限 りなく避けることが望ましいと言える.そのため,
抗がん剤調製における調製者の手指への曝露経路 の特定や曝露軽減のための抗がん剤調製方法を確 立することは重要である.

調製者の手袋への抗がん剂の曝露経路は CSTD を用いた調製方法においては，バイアル表面に付 着した抗がん剂が手指へ伝搬した可能性と抗がん 剂の溶解液をシリンジで注入後, シリンジ内筒部 分に残留した抗がん剂がシリンジプランジャーに 付着し，プランジャーに再度調製者が触れること で手袋へ抗がん剂が付着する可能性がある，海外 の報告では，CPA を溶解した薬液をシリンジで注 入後, シリンジプランジャーにCPA が付着する

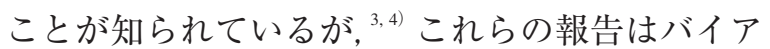
ル表面から手指を介したプランジャーへの伝搬に ついて検証されていないのみではなく, 調製に使 用したシリンジの使用回数が一定回数ではない観 察研究や, 2 回以上薬液を注入した後のデータで あり, 溶解した CPAを 1 回注入したのみの状態で, シリンジプランジャーにどの程度 CPA が付着する かは明らかになっていない。 また，これら報告は

\footnotetext{
* $\% 484-8681$ 愛知県名古屋市千種区鹿子殿1-1
} 
Becton Dickinson $^{\mathrm{TM}}$ シリンジ (Becton, Dickinson and Company, New Jersey, USA）を用いたものであり， 本邦において広く流通しているテルモシリンジ （テルモ株式会社，東京）における抗がん剂調製 後のシリンジプランジャー污染については十分に 検証がされているとは言い難い。 そこで，本試験 は調製後の手袋への抗がん剤曝露の污染経路とし て，CPAバイアル表面接触後の手袋の污染につ いて検討を行うとともに，シリンジプランジャー を介した調製者の手袋への污染の可能性について 検討を行うことを目的として，テルモシリンジ® を用いて CPA 溶解液を 1 回注入後におけるシリ ンジプランジャーに対するCPAの污染状況につ いて調査した。

\section{方 法}

本試験はすべて当院薬剤部内に設置されている 100\%室外排気型安全キャビネット (バイオハザー ド対策用キャビネット YS-B-A II B2, (株)ユヤマ, 大阪）内において同日に実施された。測定は検体 番号 1-5 と 6-10をそれぞれ抗がん剤調製経験 5 年以上の 2 名の薬剤師により実施した。 なお，定 量はシオノギ分析センターでLC/MS/MS 法を用 いて測定した。

\section{1. バイアル表面污染の検討}

包装容器から開封直後の CPA バイアル 2 バイ アル（エンドキサン ${ }^{\circledR} 500 \mathrm{mg}$ バイアル（塩野義製 薬，大阪)）をバイアルキャップを外したのち, 手袋を装着した状態でバイアルのゴム栓部分に触 れないように，側面と底面を入念に触れたのち， 手袋を密封容器内に回収し, 手袋表面に付着した CPA の定量測定を行った $(\mathrm{n}=10)$.

\section{2. シリンジ污染の検討}

新たに手袋を装着し CSTD（TEVADAPTOR ${ }^{\circledR}$, テバ製薬(株), 名古屋) と試験直前に包装開封し たテルモシリンジ $50 \mathrm{~mL}$ を用いて，エンドキサ ン $500 \mathrm{mg} 2$ バイアルを各 $25 \mathrm{~mL}$ の生理食塩水 で溶解し, 全量 $50 \mathrm{~mL}$ をシリンジで採取し, 輸 液バックに注入後に再度プランジャーを引き，図

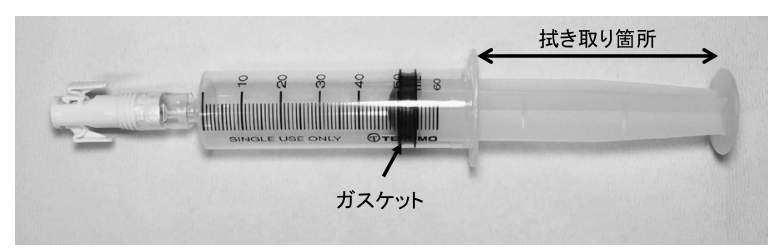

図 1 TEVADAPTOR ${ }^{\circledR}$ 装着後のシリンジ写真

1 に示す部位をエタノール綿で拭き取り，ただち にエタノール綿を密封容器へ回収し, 付着した CPAの定量測定を行った $(\mathrm{n}=10)$.

\section{結＼cjkstart果}

エンドキサン ${ }^{\circledR}$ バイアル表面接触後の手袋 10 検 体中 2 検体において, CPA が検出されたが，検 出量は最大で $2.1 \mathrm{ng}$ であった（図 2)。調製に用 いたシリンジプランジャーからは全サンプルで $\mathrm{CPA}$ が検出され, その検出量の中央值は $2.97 \mathrm{ng}$

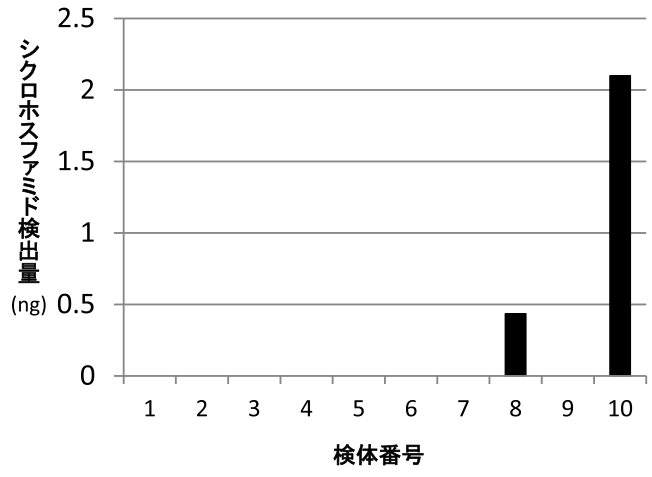

図 2 エンドキサン ${ }^{\circledR}$ バイアル表面接触後の手袋への シクロホスファミド付着量

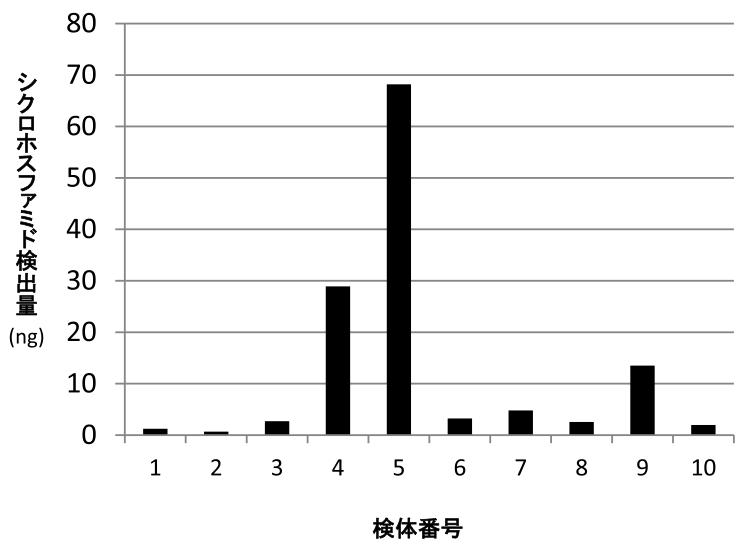

図 3 シクロホスファミド調製後のシリンジプラン ジャーに対するシクロホスファミド付着量 
（0.681-68.2 ng）であった（図 3).なお，本試 験における検出限界量は手袋抽出は $0.4 \mathrm{ng}$, シリ ンジブランジャーは $0.2 \mathrm{ng}$ であった。

\section{考察}

CPA は飛散性や残留性また細胞毒性の強さが ほかの抗がん剂よりも強く, 調製時の取り扱いに は特に注意が必要な薬剤である。CPAの皮膚へ の付着はアレルギー症状を始め, 発がん性リスク の上昇や妊㝋性障害が報告 ${ }^{6,7)}$ されており, CSTD を用いた調製や調製にかかわる薬郕師は個人用防 護具を着用して作業することが推奨されている. 過去の調査研究 ${ }^{2)}$ では CSTD を使用して調製を 行った場合でも調製者の手袋への抗がん剤の付着 は，完全に防ぐことはできて扔らず，手指への抗 がん剤の付着経路について，更なる検討が必要で ある，本試験では，バイアル接触後の手袋に付着 したCPA 量を測定するとともに，調製後のシリ ンジプランジャーに対する抗がん剤の付着の有無 を検討することで，調製者の手袋の抗がん剂污染 の伝搬経路について検討を行った。

その結果, $\mathrm{CPA}$ の溶解液を輸液バックに 1 回注 入した時点でシリンジプランジャーに CPA が付 着していることが明らかとなった。過去の報告 ${ }^{3)}$ ではシリンジプランジャーにCPA が付着した原 因として，調製前のバイアル表面に付着した CPA が調製者の手袋を介して，プランジャーに 付着した可能性について否定できていない。しか しながら，本試験においてエンドキサン®調製前 にバイアル表面接触後の手袋は CPA 測定のため に回収し，新たに手袋を装着していることから， 調製時にエンドキサンバイイアルに触れたことで バイアル表面の CPA が調製者の手袋を介して, シリンジプランジャーへ付着した可能性はそし い.それゆえ，シリンジプランジャーへの CPA の付着は CPA の溶解液をシリンジで注入後, シ リンジ内筒部分に残留したものが付着したと示唆 される。

また，エンドキサン ${ }^{\circledR}$ バイアル表面接触後の手 袋からは 10 検体中 2 検体で微量の CPA が検出さ れた，現在エンドキサンバイアルは表面の CPA
の付着は洗浄によりほとんど消失していると思わ れるが，バイアル洗浄は薬剂充填後にバイアル キャップを装着したのちに行っているため, バイ アルのゴム栓部分およびキャップ内側には CPA が残留しているものと推察される．本試験ではゴ ム栓部分に触れないよう試験を行ったが，キャッ プを取り外す過程で，一部 CPA が飛散し，それ らが手袋から検出されたと考える.しかしながら， 手袋に付着した CPA 量はプランジャーからの検 出量と比較し少なく, 調製者の手袋への曝露経路 としてはシリンジプランジャーを介した経路が大 きく寄与すると推察される.

当院薬剂部における過去の研究でもCSTDを 用いた CPA 調製後の調製者の手袋へ CPA が付着 していることが明らかとなっているが，バイアル 内で溶解した CPA を輸液バックに注入する際に, 1 回で注入した場合と比較し同一シリンジを用い て2回に分けて注入した場合のほうが調製者の手 袋への CPA の付着量が多かった（前田章光, “シ クロホスファミド調製時に扔けるシリンジの押し 子を介した曝露の可能性”, 第 24 回日本医療薬学 会年会, 2014, 名古屋). 本邦において高用量の CPA を調製する際にCPA 製剤であるエンドキサ ン バイアルの最大規格用量が $500 \mathrm{mg}$ であること から複数個のバイアルを 1 度に調製することは珍 しくない，本試験の結果より，同一シリンジを用 いた複数回の調製は, CPA が付着したシリンジ プランジャーに再度調製者が触れることで, 手袋 へのさらなる污染につながる可能性がある。 その 污染対策として海外ではすでに Equashield ${ }^{\circledR} か ゙$ 発 売され，プランジャーの污染軽減に対してその有

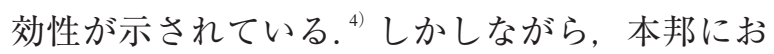
いてプランジャー污染に対応したシリンジは発売 されていないため, 複数回にわたり同一シリンジ を用いて調製を行う際には注意する必要がある。

一方，本試験に使用したテルモシリンジは同 一ロットであったが, シリンジプランジャーに対 する CPA の付着量は測定検体によりバラッキが 生じた。検体番号 1-5 は同一の薬剤師が調製を 行っているが，手技が粗略になりガスケットにゆ がみが生じたことが, CPA 付着量にバラッキが 生じた要因ではないかと推察している. そのこと 
から，調製者の手技によって，プランジャーへの CPA の付着は大きく変動する可能性があり, 調 製の際には注意が必要である.

結論として, 本試験において 1 回の CPA 溶解 液の注入作業においても, シリンジプランジャー には CPA が付着することが明らかとなった。こ れらのことを考慮すると, 同一シリンジを用いた 複数回使用は污染されたプランジャーに触れるこ とで手指への抗がん剂の曝露を増大させる可能性 があり，調製の際には十分に注意が必要と思われ る.

\section{利益相反}

本試験はテバ製薬 (株)より資金提供を受けて実 施した.

\section{引用文献}

1) Connor TH, McDiarmid MA, Preventing occupational exposures to antineoplastic drugs in health care settings, CA Cancer J Clin, 2006, 56, 354-365.

2）西垣玲奈, 紺野英里, 杉安美紀, 米村雅人, 大塚 知信, 渡邊協孝, 軍司剛宏, 戸塚ゆ加里, 若林敬二, 遠藤一司, 山本弘史, 抗がん薬による被曝防止を
目的とした閉鎖式混合調製器具の有用性の検 討, 日本病院薬剤師会雑誌, 2010, 46, 113-117.

3) Favier B, Gilles L, Latour JF, Desage M, Giammarile $\mathrm{F}$, Contamination of syringe plungers during the sampling of cyclophosphamide solutions, J Oncol Pharm Pract, 2005, 11, 1-5.

4) Smith ST, Szlaczky MC, Syringe plunger contamination by hazardous drugs: a comparative study, J Oncol Pharm Pract, 2014, 20, 381-385.

5) Sato J, Mori M, Sasaki T, Nihei S, Kumagai M, Nakayama S, Takahashi K, Kudo K, Field survey of the anticancer drug contamination in the preparation environment. Usefulness of the 5-FU monitoring by the coupon method, YAKUGAKU ZASSHI, 2014, 134, 751-756.

6) Skov T, Maarup B, Olsen J, Rorth M, Winthereik H, Lynge E, Leukaemia and reproductive outcome among nurses handling antineoplastic drugs, $\mathrm{Br} J$ Ind Med, 1992, 49, 855-861.

7) Fransman W, Roeleveld N, Peelen S, de Kort W, Kromhout H, Heederik D, Nurses with dermal exposure to antineoplastic drugs: reproductive outcomes, Epidemiology, 2007, 18, 112-119.

8) Kopjar N, Garaj-Vrhovac V, Application of the alkaline comet assay in human biomonitoring for genotoxicity: a study on Croatian medical personnel handling antineoplastic drugs, Mutagenesis, 2001, 16, 71-78. 